\title{
Implementasi Metode Weighted Product untuk Penentuan Mustahiq Zakat
}

\author{
Kunti Eliyen, Fery Sofian Efendi
}

PSDKU Polinema Kota Kediri

\section{KEYWORDS}

Zakat, mustahiq zakat, weighted product

\section{CORRESPONDENCE}

Phone: -

E-mail: sayakuntieliyen@gmail.com

\begin{abstract}
A B S S T R A A C T
Tujuan dari paper ini adalah untuk mengimplementasikan metode Weighted Product dalam pengambilan keputusan penerima zakat. Zakat merupakan bagian dari harta seseorang, yang menurut agama Islam jika harta tersebut sudah melampaui batas nishab maka diwajibkan kepada pemiliknya untuk diserahkan kepada seseorang yang berhak menerimanya dengan persyaratan tertentu atau disebut dengan mustahiq zakat. Dalam perhitungan Weighted Product digunakan beberapa kriteria acuan untuk seluruh alternatif dengan melakukan perkalian untuk menghubungkan rating atribut, di mana rating setiap atribut harus dipangkatkan dahulu dengan bobot atribut yang bersangkutan. Hasil akhir perhitungan Weighted Product adalah nilai vektor V, di mana alternatif yang mendapat nilai V tertinggi merupakan alternatif yang diprioritaskan sebagai penerima zakat.
\end{abstract}

\section{PENDAHULUAN}

Zakat berasal dari Bahasa Arab ath-thaharatu yang berarti kesucian. Sedangan menurut istilah, Zakat merupakan bagian dari harta seseorang, yang menurut agama Islam jika harta tersebut sudah melampaui batas nishab maka diwajibkan kepada pemiliknya untuk diserahkan kepada seseorang yang berhak menerimanya dengan persyaratan tertentu atau disebut dengan mustahiq zakat [1].

Badan Amil Zakat NU Kota Blitar merupakan salah satu badan yang bertugas menyalurkan zakat kepada para penerima zakat atau mustahiq. Dalam proses penentuan mustahiq, badan amil melakukan pengumpulan data terlebih dahulu berdasarkan kriteria-kriteria yang menjadi acuan dalam penentuan mustahiq. Setelah mengumpulkan data kemudian badan amil melakukan penentuan siapa saja yang berhak menerima zakat secara manual tanpa perhitungan terlebih dahulu. Proses penentuan secara manual ini akan menimbulkan masalah seperti tidak tepatnya keputusan mustahiq yang mendapat zakat karena dikhawatirkan terdapat faktor kesubjektifan dalam penentuan tersebut yang akan berakibat tidak tepatnya sasaran penyaluran zakat.

Dalam penelitian ini akan diimplementasikan salah satu metode dalam pengambilan keputusan yaitu Weighted Product (WP) untuk membantu penentuan mustahiq penerima zakat dan menghindari adanya faktor subjektifitas dalam penyaluran zakat. Decision support system atau yang lebih dikenal sebagai Sistem Pendukung Keputusan (SPK) merupakan program komputer yang menganalisis data bisnis dan menyajikannya sehingga pengguna dapat membuat keputusan bisnis dengan menentukan alternative dan kriteria [2].

Penelitian pengambilan keputusan penerima zakat pernah dilakukan oleh Asni Furoida dan Sutikno dengan menghitung kriteria status anak, tanggungan orangtua, pendapatan orangtua, indeks rumah dan kepemilikan harta menggunakan metode Simple Additive Weighting [3].

Metode weighted product pernah diterapkan oleh Basri untuk melakukan pengambilan keputusan penerimaan beasiswa berprestasi dengan menggunakan empat kriteria yaitu nilai, kehadiran, penghasilan orang tua dan jumlah tanggungan orang tua. Hasil dari penelitian disebutkan bahwa metode Wighted Product sangat baik dalam memberikan rekomendasi keputusan [4].

Pemilihan perhitungan dengan menggunakan metode Weighted Product dikarenakan keoptimalan kinerja WP dalam memberikan solusi untuk permasalahan sistem rangking. Selain itu WP merupakan metode yang perhitungannya mudah sehingga membutuhkan waktu yang relatif singkat untuk melakukan komputasi [5].

\section{STUDI PUSTAKA}

\section{Sistem Pendukung Keputusan}

Sistem Pendukung Keputusan adalah suatu sistem yang digunakan untuk mendukung pengambilan keputusan secara terkomputerisasi berdasarkan hasil analisis sejumlah data 
dengan menggunakan metode tertentu. Keputusan dalam permasalahan merupakan hasil dari memilih lebih dari satu alternatif yang ada. Sistem Pendukung Keputusan diterapkan untuk membantu melakukan analisis dalam suatu masalah yang memiliki banyak alternatif dan kriteria yang tidak terstruktur. Manfaat sistem pendukung keputusan adalah dapat memberikan keputusan yang lebih akurat berdasarkan informasi data, dapat mempersingkat waktu penyelesaian masalah dan dapat menyelesaikan masalah dengan variabel yang berbeda secara efisien. Tujuan utama SPK adalah untuk membantu melakukan perhitungan untuk data-data dengan kriteria yang kurang jelas dan kurang terstruktur sehingga dibutuhkan analisis sehingga pengambil keputusan dapat melakukan berbagai analisis dengan menggunakan model-model yang tersedia [5].

Pada studi kasus dalam penelitian ini, masalah yang akan dicari solusinya menggunakan SPK adalah calon penerima zakat berdasarkan kriteria yang ditentukan.

\section{Mustahiq Zakat}

Orang-orang yang berhak menerima zakat (mustahiq zakat) menurut kitab Fathul Qarib antara lain adalah orang-orang yang termasuk golongan fakir dan miskin. Seseorang dikatakan fakir adalah, a) orang yang sama sekali tidak mempunyai harta maupun pekerjaan, b) orang yang mempunyai harta namun tidak mempunyai pekerjaan, dan harta yang dimiliki tidak cukup untuk memenuhi kebutuhan selama umumnya usia (63 tahun), c) orang yang bekerja dengan jenis pekerjaan yang layak dan berpenghasilan tetapi hasil dari pekerjaan tersebut tidak dapat memenuhi kebutuhan hidunya, d) orang yang mempunyai harta simpanan atau harta hasil bekerja, namun harta tersebut dianggap haram menurut agama. Sehingga orang-orang tersebut termasuk dari golongan fakir yang berhak mendapat zakat.

Sedangkan orang miskin adalah orang yang mempunyai harta atau pekerjaan, di mana masing-masing harta dan pekerjaannya dapat menjadi sumber penghasilan hidup, tetapi tidak mencukupinya; seperti orang tersebut membutuhkan (belanja) 10000 rupiah, sementara penghasilan yang didapat olehnya adalah 7000 rupiah.

Perbedaan yang paling mendasar antara fakir dan miskin adalah penghasilan fakir jauh dari mencukupi, tidak sampai setengah dari yang diperlukan. Sedangkan penghasilan orang miskin meskipun tidak mencukupi namun jumlahnya lebih dari setengah dari yang diperlukan. Kebutuhan yang harus dicukupi dalam kontek ini adalah dalam hal sandang, pangan, papan dan hal apa saja yang diperlukan tanpa berlebihan dan kekurangan. Sehingga ketika seseorang tidak tecukupi dalam hal tersebut secara layak, maka baginya boleh menerima zakat [6].

\section{METODE}

Weighted Product merupakan suatu metode pengambilan keputusan multi-kriteria yang digunakan untuk menyelesaikan kasus yang mempunyai data dengan banyak atribut. Metode WP menggunakan perkalian untuk menghubungkan rating atribut, di mana rating setiap atribut harus dipangkatkan dahulu dengan bobot atribut yang bersangkutan [7].

Metode WP banyak digunakan dalam pengambilan keputusan dikarenakan metode ini mampu dalam pencarian solusi terbaik pada sistem perangkingan dengan proses perhitungan yang cukup mudah tanpa memerlukan waktu yang lama dalam perhitungan [8].
Langkah-langkah penyelesaian masalah menggunakan metode Weighted Product untuk pemilihan alternatif mustahiq zakat adalah sebagai berikut:

1. Penentuan kriteria yang dijadikan dasar dalam penentuan mustahiq zakat

Kriteria disimbolkan dengan $\mathrm{C} i$, di mana $i$ merupakan banyaknya kriteria yang ditentukan untuk dijadikan acuan dalam pengambilan keputusan.

2. Menentukan peringkat kecocokan untuk kriteria Membuat matriks keputusan dengan membuat peringkat kecocokan pada setiap kriteria.

3. Normalisasi bobot

Normalisasi bobot pada metode WP dilakukan dengan melakukan pembagian bobot setiap kriteria dengan jumlah keseluruhan bobot kriteria.

Nilai total normalisasi bobot untuk seluruh kriteria harus memenuhi persamaan:

$$
\sum_{j=1}^{n} w_{j}=1
$$

\section{Keterangan: $\mathrm{W}=$ bobot kriteria}

4. Menghitung nilai preferensi untuk alternatif sebagai vektor $\mathrm{S}$ Nilai preferensi untuk alternatif dihitung dengan menggunakan persamaan:

$S i=\prod_{j=1}^{n} x_{i j}{ }^{w j}$

Keterangan:

$\mathrm{S}=$ preferensi alternative

$\mathrm{w}=$ bobot kriteria

$\mathrm{X}=$ nilai kriteria

$\mathrm{i}=$ alternatif ke-i sampai dengan $\mathrm{n}$

$\mathrm{j}=$ kriteria

Vektor S dihitung dengan melakukan seluruh perkalian nilai kriteria 1 hingga $\mathrm{n}$ dengan memangkatkan w sebagai bobot normalisasi tiap kriteria, yang akan bernilai positif apabila w merupakan atribut keuntungan (benefit) dan bernilai negatif apabila w merupakan atribut biaya (cost).

5. Menghitung nilai preferensi relatif sebagai vektor $\mathrm{V}$ Vektor $\mathrm{V}$ merupakan nilai preferensi relatif yang akan digunakan untuk mencari peringkat dari hasil perhitungan setiap alternatif.

$$
\mathrm{Vi}=\frac{\prod_{j=1}^{n} x_{i j}{ }^{w j}}{\prod_{j=1}^{n}\left(x_{j}^{*}\right)}
$$

6. Membuat peringkat nilai vector $\mathrm{V}$

Pada tahap ini akan diketahui alternatif yang memiliki nilai Vi tertinggi yang merupakan hasil dari keputusan [9].

\section{HASIL DAN PEMBAHASAN}

Pada penelitian ini, permasalahan yang dibahas adalah pengambilan keputusan penerima zakat pada Badan Amil Zakat 
NU Kota Blitar dengan menggunakan metode Weighted Product (WP). Berikut merupakan langkah yang dilakukan dalam proses pengambilan keputusan;

a. Menentukan kriteria dan bobot kriteria

Langkah awal yang dilakukan adalah menentukan kriteria dan nilai bobot kriteria yang dijadikan acuan dalam pengambilan keputusan. Berikut merupakan kriteria-kriteria yang digunakan dalam penentuan mustahiq zakat:

Tabel 1. Kriteria dan Bobot Kriteria

\begin{tabular}{|l|l|l|l|}
\hline Kriteria & \multicolumn{1}{|c|}{ Keterangan } & Kategori & $\begin{array}{c}\text { Bobot } \\
\text { Kriteria }\end{array}$ \\
\hline C1 & Tempat Tinggal & Benefit & 5 \\
\hline C2 & Penghasilan & Cost & 5 \\
\hline C3 & Status Pekerjaan & Benefit & 4 \\
\hline C4 & Jumlah Tanggungan & Benefit & 4 \\
\hline C5 & $\begin{array}{l}\text { Kebutuhan Hidup } \\
\text { Setiap Bulan }\end{array}$ & Benefit & 3 \\
\hline
\end{tabular}

b. Menentukan nilai skala dari setiap kriteria

Dalam penelitian ini data yang diperoleh merupakan data kualitatif sehingga diperlukan nilai skala dari setiap kriteria guna dapat dengan mudah diimplementasikan untuk perhitungan.

Tabel 2. Skala Kriteria Tempat Tinggal

\begin{tabular}{|l|c|}
\hline \multicolumn{1}{|c|}{ Kualifikasi } & Skala \\
\hline Tidak punya tempat tinggal & 5 \\
\hline Menumpang & 4 \\
\hline Mengontrak & 3 \\
\hline Mukim dengan keluarga & 2 \\
\hline Milik pribadi & 1 \\
\hline
\end{tabular}

Tabel 3. Skala Kriteria Penghasilan

\begin{tabular}{|l|c|}
\hline \multicolumn{1}{|c|}{ Kualifikasi } & Skala \\
\hline $2500000-3000000$ & 5 \\
\hline $2000000-2500000$ & 4 \\
\hline $1500000-2000000$ & 3 \\
\hline $1000000-1500000$ & 2 \\
\hline $500000-1000000$ & 1 \\
\hline
\end{tabular}

Tabel 4. Skala Kriteria Status Pekerjaan

\begin{tabular}{|l|c|}
\hline \multicolumn{1}{|c|}{ Kualifikasi } & Skala \\
\hline Tidak bekerja & 5 \\
\hline Pekerja serabutan & 4 \\
\hline Pegawai kontrak & 3 \\
\hline Usaha sendiri & 2 \\
\hline Pegawai tetap & 1 \\
\hline
\end{tabular}

Tabel 5. Skala Kriteria Banyak Tanggungan

\begin{tabular}{|l|c|}
\hline \multicolumn{1}{|c|}{ Kualifikasi } & Skala \\
\hline$>4$ orang & 5 \\
\hline 4 orang & 4 \\
\hline 3 orang & 3 \\
\hline 2 orang & 2 \\
\hline 1 orang & 1 \\
\hline
\end{tabular}

Tabel 6. Skala Kriteria Kebutuhan Hidup

\begin{tabular}{|l|c|}
\hline \multicolumn{1}{|c|}{ Kualifikasi } & Skala \\
\hline $2500000-3000000$ & 5 \\
\hline $2000000-2500000$ & 4 \\
\hline $1500000-2500000$ & 3 \\
\hline $1000000-1500000$ & 2 \\
\hline $500000-1000000$ & 1 \\
\hline
\end{tabular}

c. Memasukkan data alternatif mustahiq zakat

Berikut adalah data alternatif mustahiq zakat dengan

kriteria-kriteria yang telah ditentukan:

Tabel 7. Data Alternatif Mustahiq Zakat

\begin{tabular}{|l|l|l|r|l|r|l|}
\hline $\begin{array}{c}\text { N } \\
\text { o }\end{array}$ & $\begin{array}{c}\text { Altern } \\
\text { atif }\end{array}$ & \multicolumn{1}{|c|}{$\begin{array}{c}\text { Tempat } \\
\text { Tinggal }\end{array}$} & Penghasilan & $\begin{array}{c}\text { Status } \\
\text { Pekerjaan }\end{array}$ & $\begin{array}{c}\text { Jumlah } \\
\text { Tanggung } \\
\text { an }\end{array}$ & $\begin{array}{c}\text { Kebutuhan } \\
\text { Perbulan }\end{array}$ \\
\hline 1 & A1 & Menumpang & 1200000 & $\begin{array}{l}\text { Pekerja } \\
\text { serabutan }\end{array}$ & $\begin{array}{l}2000000- \\
2500000\end{array}$ \\
\hline 2 & A2 & Milik pribadi & 1500000 & $\begin{array}{l}\text { Pegawai } \\
\text { tetap }\end{array}$ & $\begin{array}{l}2000000- \\
2500000\end{array}$ \\
\hline 3 & A3 & $\begin{array}{l}\text { Mukim dengan } \\
\text { keluarga }\end{array}$ & 1500000 & $\begin{array}{l}\text { Pegawai } \\
\text { tetap }\end{array}$ & 2 & $\begin{array}{l}2000000- \\
2500000\end{array}$ \\
\hline 4 & A4 & $\begin{array}{l}\text { Tidak punya } \\
\text { tempat tinggal }\end{array}$ & 700000 & $\begin{array}{l}\text { Pekerja } \\
\text { serabutan }\end{array}$ & 2 & $\begin{array}{l}1000000- \\
1500000\end{array}$ \\
\hline 5 & A5 & $\begin{array}{l}\text { Tidak punya } \\
\text { tempat tinggal }\end{array}$ & 500000 & $\begin{array}{l}\text { Pekerja } \\
\text { serabutan }\end{array}$ & 2 & $\begin{array}{l}1500000- \\
1500000\end{array}$ \\
\hline 6 & A6 & $\begin{array}{l}\text { Mukim dengan } \\
\text { keluarga }\end{array}$ & 1100000 & $\begin{array}{l}\text { Pegawai } \\
\text { kontrak }\end{array}$ & 2000000 \\
\hline 7 & A7 & Mengontrak & 1000000 & $\begin{array}{l}\text { Pekerja } \\
\text { serabutan }\end{array}$ & $\begin{array}{l}1500000- \\
2000000\end{array}$ \\
\hline 8 & A8 & Mengontrak & 1100000 & $\begin{array}{l}\text { Pekerja } \\
\text { serabutan }\end{array}$ & 3 & $\begin{array}{l}1500000- \\
2000000\end{array}$ \\
\hline 9 & A9 & Mengontrak & 1500000 & $\begin{array}{l}\text { Pekerja } \\
\text { serabutan }\end{array}$ & $\begin{array}{l}1000000- \\
1500000\end{array}$ \\
\hline 1 & A10 & Mengontrak & 1300000 & $\begin{array}{l}\text { Usaha } \\
\text { sendiri }\end{array}$ & $\begin{array}{l}500000- \\
1000000\end{array}$ \\
\hline 0
\end{tabular}

d. Merubah nilai kriteria alternatif

Setelah data alternatif dimasukkan kemudian mengubah nilai skala masing-masing kriteria alternatif sesuai dengan nilai skala yang ditentukan.

Tabel 8. Perubahan Nilai Skala Kriteria Alternatif

\begin{tabular}{|c|c|c|c|c|c|}
\hline Alternatif & C1 & C2 & C3 & C4 & C5 \\
\hline A1 & 4 & 2 & 4 & 3 & 4 \\
\hline A2 & 1 & 3 & 1 & 4 & 4 \\
\hline A3 & 2 & 3 & 1 & 2 & 4 \\
\hline A4 & 5 & 1 & 4 & 2 & 2 \\
\hline A5 & 5 & 1 & 4 & 2 & 2 \\
\hline A6 & 2 & 2 & 3 & 2 & 3 \\
\hline A7 & 3 & 1 & 4 & 2 & 3 \\
\hline A8 & 3 & 2 & 4 & 3 & 3 \\
\hline A9 & 3 & 2 & 4 & 2 & 2 \\
\hline A10 & 3 & 2 & 2 & 1 & 1 \\
\hline
\end{tabular}

Data perubahan nilai pada Tabel VIII menghasilkan matriks sebagai berikut; 


$\begin{array}{lllll}4 & 2 & 4 & 3 & 4 \\ 1 & 3 & 1 & 4 & 4 \\ 2 & 3 & 1 & 2 & 4 \\ 5 & 1 & 4 & 2 & 2 \\ 5 & 1 & 4 & 2 & 2 \\ 2 & 2 & 3 & 2 & 3 \\ 3 & 1 & 4 & 2 & 3 \\ 3 & 2 & 4 & 3 & 3 \\ 3 & 2 & 4 & 2 & 2 \\ 3 & 2 & 2 & 1 & 1\end{array}$

e. Menghitung normalisasi bobot

Bobot yang dihitung normalisasinya merupakan bobot kriteria pada Tabel 1. Jumlah normalisasi bobot harus memenuhi persamaan 1 sehingga,

$\mathrm{w}=(5,5,4,4,3)$

$\mathrm{w} 1=5 /(5+5+4+4+3)=0,238095238$

$\mathrm{w} 2=5 /(5+5+4+4+3)=0,238095238$

$\mathrm{w} 3=4 /(5+5+4+4+3)=0,19047619$

$\mathrm{w} 4=4 /(5+5+4+4+3)=0,19047619$

w $5=3 /(5+5+4+4+3)=0,142857143$

$\mathrm{w} 1+\mathrm{w} 2+\mathrm{w} 3+\mathrm{w} 4+\mathrm{w} 5=1$

$0,238095238+0,238095238+0,19047619+0,19047619+$

$0,142857143=1$

Tabel 9. Hasil Perhitungan Sebelum Perangkingan

\begin{tabular}{|l|l|}
\hline \multicolumn{1}{|c|}{ Alternatif } & \multicolumn{1}{c|}{ Hasil } \\
\hline A1 & 0,123800913 \\
\hline A2 & 0,065549518 \\
\hline A3 & 0,067749214 \\
\hline A4 & 0,129099925 \\
\hline A5 & 0,129099925 \\
\hline A6 & 0,088280056 \\
\hline A7 & 0,12113252 \\
\hline A8 & 0,110950212 \\
\hline A9 & 0,096923938 \\
\hline A10 & 0,067413779 \\
\hline
\end{tabular}

f. Menghitung vektor $\mathrm{S}$

Vektor S dihitung dengan persamaan 2, dalam perhitungan vektor $\mathrm{S}$ pangkat untuk kategori benefit akan bernilai positif, sedangkan pangkat untuk kategori cost akan bernilai negatif.

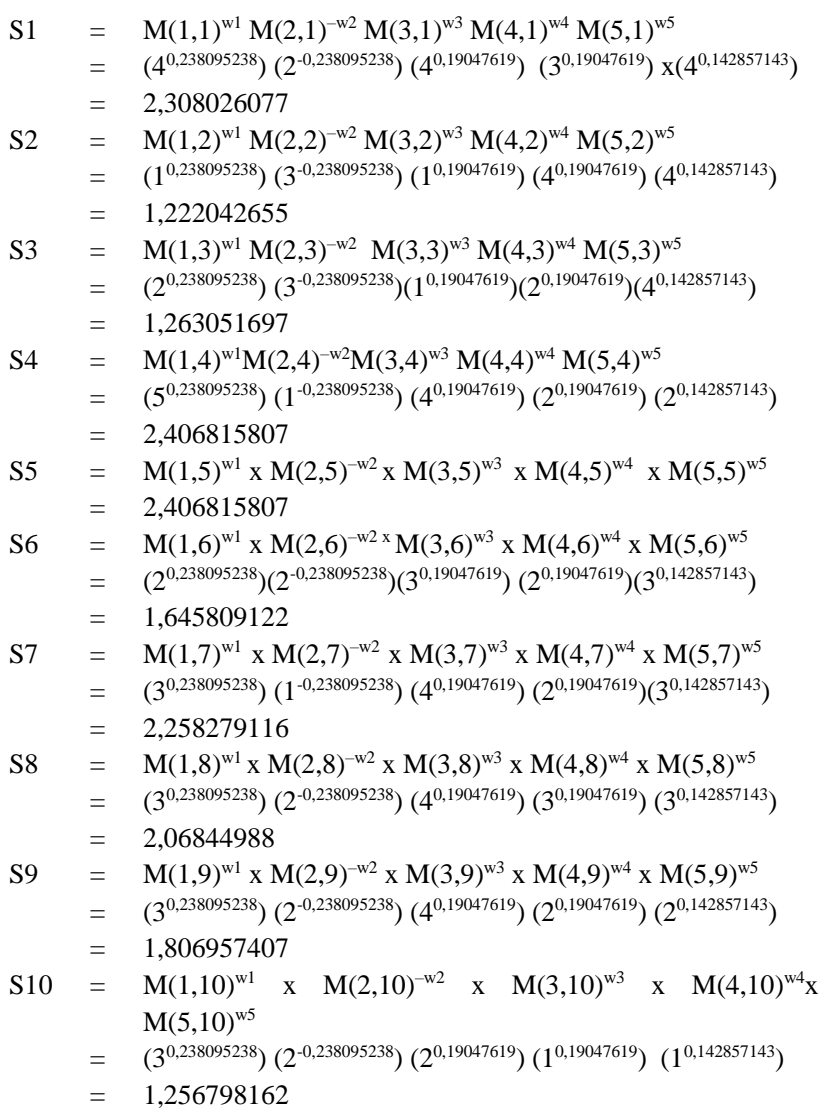

g. Menghitung vektor $\mathrm{V}$

Berdasarkan persamaan 3, vector $\mathrm{V}$ dihitung dengan membagi nilai vector Si dengan jumlah total vektor Si.

\begin{tabular}{|c|c|c|c|}
\hline V1 & $=$ & $\mathrm{S} 1 / \sum S i$ & \\
\hline & $=$ & $2,308026077 / 18,64304573$ & $=0,123800913$ \\
\hline $\mathrm{V} 2$ & $=$ & $\mathrm{S} 2 / \sum S i$ & \\
\hline & $=$ & $1,222042655 / 18,64304573$ & $=0,065549518$ \\
\hline V3 & $=$ & $\mathrm{S} 3 / \sum S i$ & \\
\hline & $=$ & $1,263051697 / 18,64304573$ & $=0,067749214$ \\
\hline V4 & $=$ & $\mathrm{S} 4 / \sum S i$ & \\
\hline & $=$ & 2,406815807 / 18,64304573 & $=0,129099925$ \\
\hline V5 & $=$ & $\mathrm{S} 5 / \sum S i$ & \\
\hline & $=$ & $2,406815807 / 18,64304573$ & $=0,129099925$ \\
\hline V6 & $=$ & $\mathrm{S} 6 / \sum S i$ & \\
\hline & $=$ & 1,645809122 / 18,64304573 & $=0,088280056$ \\
\hline V7 & $=$ & $\mathrm{S} 7 / \sum S i$ & \\
\hline & $=$ & $2,258279116 / 18,64304573$ & $=0,12113252$ \\
\hline V8 & $=$ & $\mathrm{S} 8 / \sum S i$ & \\
\hline & $=$ & $2,06844988 / 18,64304573$ & $=0,110950212$ \\
\hline V9 & $=$ & $\mathrm{S} 9 / \sum S i$ & \\
\hline & $=$ & $1,806957407 / 18,64304573$ & $=0,096923938$ \\
\hline V10 & $=$ & $\mathrm{S} 10 / \sum S i$ & \\
\hline & $=$ & $1,256798162 / 18,64304573$ & $=0,067413779$ \\
\hline
\end{tabular}

h. Perangkingan nilai

Hasil perhitungan vektor $\mathrm{V}$ selanjutnya dilakukan perangkingan untuk seluruh alternatif dari nilai terbesar hingga terkecil. Dari perangkingan tersebut maka diperoleh keputusan alternatif yang mendapat nilai tertinggi adalah alternatif yang berhak menerima zakat. 
Tabel 10. Hasil Perhitungan Setelah Perangkingan

\begin{tabular}{|l|l|l|}
\hline Alternatif & Hasil & Rangking \\
\hline A4 & 0,129099925 & 1 \\
\hline A5 & 0,129099925 & 1 \\
\hline A1 & 0,123800913 & 2 \\
\hline A7 & 0,12113252 & 3 \\
\hline A8 & 0,110950212 & 4 \\
\hline A9 & 0,096923938 & 5 \\
\hline A6 & 0,088280056 & 6 \\
\hline A3 & 0,067749214 & 7 \\
\hline A10 & 0,067413779 & 8 \\
\hline A2 & 0,065549518 & 9 \\
\hline
\end{tabular}

Tabel 10 menunjukkan bahwa dari perhitungan seluruh alternative dengan menggunakan Weighted Product dihasilkan keputusan bahwa alternative A4 dan A5 mendapatkan nilai tertinggi dan menjadi prioritas utama untuk mendapatkan zakat.

\section{KESIMPULAN}

Berdasarkan hasil uji coba menggunakan data alternatif mustahiq zakat, metode Weighted Product berhasil diimplementasikan untuk perhitungan kriteria alternati mustahiq zakat dengan menggunakan lima kriteria yaitu tempat tinggal, penghasilan, status pekerjaan, jumlah tanggungan dan banyak kebutuhan hidup per bulan . Dari uji coba yang telah dilakukan, disimpulkan bahwa metode weighted product merupakan salah satu metode pengambilan keputusan multi kriteria yang proses perhitungannya tidak terlalu rumit dan mudah diimplementasikan.

\section{DAFTAR PUSTAKA}

[1] Didin Hafhiduddin, Zakat dalam Perekonomian Modern, Jakarta: Gema Insani Press, 2002, hlm. 7.

[2] Sholikhah, F., Satyareni, D. H., \& Anugerah, C. S. (n.d.). Perancangan Sistem Pendukung Keputusan Pemilihan Pelanggan Terbaik Menggunakan Metode Simple Additive Weighting ( SAW ) Pada Bravo Supermarket Jombang. 2, 40-50.

[3] Furoida, A., \& Sutikno, S. (2018). Sistem Pendukung Keputusan Penerima Zakat Dengan Metode Simple Additive Weighting. InfoTekJar (Jurnal Nasional Informatika Dan Teknologi $\begin{array}{lrr}\text { Jaringan), } & \text { 2(1), 73-78. }\end{array}$ https://doi.org/10.30743/infotekjar.v2i1.160

[4] Basri. (2017). Metode Weightd Product (Wp) Dalam Sistem Pendukung Keputusan Penerimaan Beasiswa Prestasi. Jurnal INSYPRO (Information System and Processing), 2(1), 1-6. https://doi.org/https://doi.org/10.24252/insypro.v2i1.2474.g2610

[5] Ahmadi, A., \& Wiyanti, D. T. (2014). Implementasi Weighted Product (WP) dalam Penentuan Penerima Bantuan Langsung Masyarakat PNPM Mandiri Perdesaan. Seminar Nasional Aplikasi Teknologi Informasi, 19-22.

[6] Mubarok, A.H. 2017. Fiqh Idola (1) Terjemah Fathul Qarib. Kediri: Mukjizat.

[7] Kusumadewi, dkk. 2006. Fuzzy Multi-Attribute Decision Making: (Fuzzy MADM). Yogyakarta: Graha Ilmu.

[8] Ahmadi, A., \& Wiyanti, D. T. (2014). Implementasi Weighted Product ( WP ) dalam Penentuan Penerima Bantuan Langsung Masyarakat PNPM Mandiri Perdesaan. Seminar Nasional Aplikasi Teknologi Informasi (SNATI), 19-22.

[9] Roni, Sumijan \& Santony, J. (2019). Metode Weighted Product dalam Pemilihan Penerima Beasiswa Bagi. Jurnal RESTI (Rekayasa Sistem dan Teknologi Informasi), 87-93. 